Indonesian Journal of Global Health Research

Volume 3 Number 3, August 2021, pp. 341 - 352

e-ISSN 2715-1972; p-ISSN 2714-9749

http://jurnal.globalhealthsciencegroup.com/index.php/IJGHR

\title{
MANAGEMENT OF FREE HEALTH SERVICES IN HOSPITAL
}

\author{
Siti Mardiyanti*, Dewi Rahayu, Ahmad Karbito, Atikah Adyas \\ Magister of Public Health, Universitas Mitra Indonesia, Jl. ZA. Pagar Alam No.7, Gedong Meneng, Kec. \\ Rajabasa, Kota Bandar Lampung, Lampung 40115, Indonesia \\ *sitimardiyanti041196@gmail.com
}

\begin{abstract}
The Government of Indonesia is obliged to provide guarantees for the fulfillment of the right to a healthy life for every citizen by enforcing the Social Security Administration (BPJS) for Health. The success of hospitals in carrying out their functions is marked by an increase in the quality of hospital services. To implement the implementation of SJSN in the BPJS program, the phenomenon of existing problems where the management of free health services in hospitals has not been carried out optimally, seeing some complaints in the community, therefore it is necessary to study the management of health services in terms of input, process and output. and 5M management at Tjokrodipo Hospital, Bandar Lampung City. This study aims to determine and describe the Management of Free Health Services at Tjokrodipo Hospital, Bandar Lampung City in 2021. This research is a qualitative study with a descriptive approach. The time of the study was carried out from May to June 2021 in Tjokrodipo Hospital Bandar Lampung Research subjects were selected using purposive sampling technique, researchers used data triangulation techniques and data processing carried out in this study was source triangulation. not available for BPJS patients, so patients are advised to look for other dispensaries, medical equipment such as patient beds are still lacking because during the pandemic, the availability of health human resources (HR), such as dentists and specialists are not in accordance with class $\mathrm{C}$ hospital standards, patients feel that the free health services provided are not good, the average patient complains of a lack of equipment such as uncomfortable beds and rooms because there are many patients.
\end{abstract}

Keywords: free health services; hospital; management

\begin{tabular}{|ccc|}
\hline \multicolumn{1}{|c}{$\begin{array}{c}\text { First Received } \\
\text { 14 July 2021 }\end{array}$} & $\begin{array}{c}\text { Revised } \\
\text { 20 July 2021 }\end{array}$ & \multicolumn{1}{c|}{$\begin{array}{c}\text { Accepted } \\
\text { Final Proof Received } \\
\text { 25 July 2021 }\end{array}$} \\
\hline \multicolumn{1}{|c|}{ 24 2021}
\end{tabular}

\section{INTRODUCTION}

Health is a state of well-being that includes physical, mental and social well-being, which is not only free from disease or disability. Health is a right for every citizen which is protected by the 1945 Constitution (UU No. 36 of 2009). The Indonesian government is obliged to provide guarantees for the fulfillment of the right to a healthy life for every citizen by enforcing the Social Security Administration (BPJS) for Health. BPJS Kesehatan organizes the National Health Insurance (JKN) program which aims to reach every citizen (Universal Health Coverage) to gain access and convenience in health services (Khariza, 2015). The success of the hospital in carrying out its functions is marked by an increase in the quality of hospital services. To implement the SJSN implementation in the BPJS program, health institutions, especially hospitals, must display their quality in providing good and appropriate services to consumers based on professional standards, so that they are expected to meet the expectations of the community or consumers (UU RI No. 44 of 2009). Health services that should be received by the community, especially the poor, are uncomplicated, easy and cheap. Both administrative and retribution matters, not only because of the many complaints from 
the public who feel disappointed with the services received in terms of quality, ease of administration and levies, the good nature of the apparatus includes moral integrity and intellectual professionalism.

The disadvantage of BPJS Health is that there is a tiered method when making claims, BPJS health services can only protect themselves in the territory of Indonesia, and queuing is not only in terms of registering and making changes to data, when participants will also go to the hospital, the queues are long too participants have to face. Finally, the drawback of BPJS Kesehatan is that there is no opportunity to get class 1 facilities. During this COVID-19 pandemic, it is mandatory to be a BPJS Health participant, even though the person concerned already has private insurance, as well as the determined contributions. Meanwhile, the Covid19 pandemic continues to have an impact on the community's economic joints, thus affecting people's purchasing power (Zahri, 2021).

Independent participants are the affected group, because they pay contributions from their own funds, and mostly work in the informal sector, a sector that is actually very vulnerable to the crisis due to the Covid-19 pandemic, especially for informal sector workers in rural areas. The increase in fees caused various reactions, some of them lowered their membership status to a lower class and piled up in class III. The results of a survey conducted by the LIPI Population Research Center before the increase in BPJS Health contributions found that $29.6 \%$ of informal sector workers felt that the large contributions were burdensome for the household economy, especially if the increase in contributions occurred during this pandemic (Hafina, 2021).

The Lampung Provincial Government cooperates in each region to synergize in providing health services, one of the forms of cooperation is in Bandar Lampung City, namely at the Dr. A. Dadi Tjokrodipo. This hospital is owned by the government which also seeks to provide free health services for the community. In supporting this collaboration, Mayor Regulation Number 24 of 2014 concerning health services was issued. The regulation became the basis for the Bandar Lampung City government's policy in the free health service program for the community to provide social protection in the health sector to ensure the poor. The program listed in this regulation is the Social Security Administering Body (BPJS) which consists of the Healthy Indonesia Card (KIS).

The community's need for this program is very large, for that all employees and the medical team at the Dr. A. Dadi Tjokrodipo is required to be able to provide optimal health services in accordance with the needs and desires of the community, especially the poor. Regional General Hospital Dr. A. Dadi Tjokrodipo has the same stratification of health services, namely third class or type $C$ health services, free health service activities by the government program at Dr. Hospital. A.dadi Tjokrodipo, namely BPJS for the people of Bandar Lampung and Outside Bandar Lampung. One of the activities faced by many customers or patients at the Regional General Hospital Dr. A. Dadi Tjokrodipo is an administrative service, namely the administration of free health services. With the increasing demand from the community for quality and affordable health facilities, various efforts have been taken to fulfill these expectations. Health services are required to provide satisfaction to patients. The main requirements for good health services are that these services must be available in the community (available) and are continuous (continuous), secondly, good health services are what is acceptable to the community and appropriate (appropriate), and the third is good health services. is accessible (accessible) by the community, the fourth is easily accessible (affordable) by the community, the fifth is quality (Azwar, 2010). 
Health service itself is a subsystem whose main objectives are promotive (maintaining and improving health), preventive (prevention), curative (healing), and rehabilitation (recovery) health of individuals, families, groups or communities, the environment. The purpose of the subsystem here is the subsystem in health services which includes: input, process, output, impact and feedback (Nothoadmojo, 2010). Research conducted by Widyawati (2019) where the research results for the input component, policies have not been socialized optimally, human resources are still lacking, and infrastructure facilities in inpatient rooms are still lacking. The process component, the dimension of tangibility quality, there are shortcomings in the facilities in the inpatient room such as the absence of curtains, air conditioners and crowded rooms, the dimensions of reliability, responsiveness, assurance, and empathy are well assessed and the hospital claim submission process is always late every month. because the hospital has not used SIMRS. The output component of the Tangibility dimension of the respondent is not satisfied, the quality dimension of reliability, responsiveness, assurance, empathy has been able to answer the respondent's needs.

From this phenomenon, so that health services can achieve the desired goals, and patients feel their needs are being met, in this case management elements are needed. These management elements are better known as the $5 \mathrm{M}$. According to Herujito (2010) management has five elements (5M) namely Man (human labor), Money (Money Required to achieve goals), Methods (systems or ways to achieve goals). ), Materials (materials or equipment needed) and Machines (machines needed). Based on the author's preliminary study conducted in November 2020, such as the lack of socialization to employees and the public, many participants complained about long service queues, short hospitalization time limits for patients using BPJS services, even BPJS service users experienced service discrimination, so they had to switch. to public services. BPJS which has just begun to be realized, still needs a process to run well, there are still many obstacles faced both for employees, doctors, and the public who will register to get BPJS services.

Even though it is clearly stated in Law 36/2009 it is emphasized that everyone has the same rights in obtaining access to resources in the health sector and obtaining health services that are safe, quality, and affordable. On the other hand, everyone also has the obligation to participate in the social health insurance program, so the phenomenon of existing problems where the management of free health services in hospitals has not been carried out optimally, seeing some complaints in the community, therefore it is necessary to study the management of health services seen through the input, process and output aspects as well as $5 \mathrm{M}$ management, this study aims to determine and describe The management of free health service in hospital.

\section{METHOD}

This research is a qualitative study with a descriptive approach. The time of the study was carried out from May to June 2021 in Tjokrodipo Hospital Bandar Lampung Research subjects were selected using purposive sampling technique, researchers used data triangulation techniques and data processing carried out in this study was source triangulation.

\section{RESULTS}

\section{Input}

\section{Policy}

Based on the results of the study, it was found that Tjokrodipo Hospital, Bandar Lampung City, did not have a special internal policy regarding the BPJS program. This is supported by the results of interviews with informants who said that the policy regarding the 
implementation of the BPJS program at Tjokrodipo Hospital Bandar Lampung City was the same, namely accepting patients from Bandar Lampung and patients outside Bandar Lampung without any specialization between the two. Policies are regulations or rules that are used as guidelines in the effort to implement BPJS in Tjokrodipo Hospital, Bandar Lampung City. One of the policies regarding BPJS in hospitals is the INA-CBG's tariff. According to the Regulation of the Health Social Security Administering Body Number 1 of 2014 states that the INA-CBG's tariff is the amount of claim payment by BPJS Health to Advanced Health Facilities for service packages based on disease diagnosis groupings.

According to Putra (2014) in his research said that INA-CBG's is a classification of patient care episodes designed to create classes that are relatively homogeneous in terms of resources used and contain patients with similar clinical characteristics. Hospitals will receive payments based on the average cost spent for a diagnosis group. Classification of each stage of similar health services into groups that have relatively the same meaning. Each patient admitted to a hospital is classified into a similar group with the same clinical symptoms and relatively the same cost of treatment.

Research conducted by Khariza (2015) on the national health insurance program, if there is a change in regulations and instructions related to the implementation of the national health insurance program at Menur Mental Hospital, formal meetings become one of the effective ways of delivering and distributing information to all sections. Hospital. Raymanel in Ernawati and Azkha's research (2018) stated that the determination of written policies is important because in the stages the process will have a clear and definite flow so that it can become the basis for all staff and socialization of all employees to be carried out.

The INA-CBG's policy at Tjokrodipo Hospital, Bandar Lampung City still has a problem, namely the delay in disbursing claims. This of course will be a problem for the hospital because this will have an impact on the services that will be received by patients. The delay in claiming is also an implication of the officer not being able to complete his work obligations on time. The problem for late claims is a priority that must be resolved by the Hospital and BPJS immediately, on the one hand the role of the Hospital as a health service provider will be disrupted if funding is hampered. In this case, of course, it is very necessary to have good cooperation between BPJS and the Hospital.

\section{Human Resources (HR) Health}

Based on the Regulation of the Minister of Health of the Republic of Indonesia No. 56 of 2014 concerning Classification and Licensing of Hospitals, it is stated that the number of general practitioners for standard $\mathrm{C}$ class hospitals is 9 people, dentists are 2 people and specialist doctors for basic medical services are 2 people and each - 1 specialist doctor each for supporting medical services. Based on the results of the study, it was found that the availability of health human resources at Tjokrodipo Hospital, Bandar Lampung City was not sufficient and not in accordance with the standards of class $\mathrm{C}$ hospitals, especially dentists and specialists. This is supported by the results of interviews with informants who said that the number of dentists and child specialists at Tjokrodipo Hospital Bandar Lampung City was still lacking, namely 1 person each, while the standard C class hospital was 2 people each. The availability of general practitioners and nurses, especially in isolation rooms, is also still lacking because some doctors and nurses are infected with Covid-19 and are undergoing independent isolation. 
According to Gulo (2015) in his research stated that Human Resources is a very important domain for the formation of a quality service. Human Resources that are in quantity and quality in accordance with standards are needed as support in creating services that become filters in reducing referral services that are not in accordance with the requirements. Research conducted by Khariza (2015), on a descriptive study of the factors that can affect the success of the implementation of the national health insurance program at the Menur Mental Hospital in Surabaya, and found that an adequate quantity of human resources is needed to maximize existing health services. The large number of people also demands an increase in the number of human resources.

Research conducted by Saputra et al (2015), in addition to quantity, the distribution of human resources for health service providers is very important, in the implementation of JKN (January-June 2014), the quantity and distribution of human resources for health service providers is still lacking. Regarding health human resources at Tjokrodipo Hospital, Bandar Lampung City, there have actually been efforts to increase in terms of numbers, but the problem is that there is a distance factor, namely it is difficult to invite specialist doctors to stay at Tjokrodipo Hospital, Bandar Lampung City and have not dared to pay doctor fees with a package system. In this case, it is expected that the hospital will add to the health human resources at Tjokrodipo Hospital, Bandar Lampung City.

\section{Medicines and Medical Devices}

According to the Regulation of the Minister of Health of the Republic of Indonesia No. 28 of 2014 concerning Guidelines for the Implementation of the BPJS Program states that drug services for BPJS participants in FKRTL are carried out by pharmacists at the pharmacy installation of the main hospital/clinic/pharmacy in accordance with the provisions of the legislation. Drug services for BPJS participants at health facilities refer to the list of drugs listed in Fornas and drug prices listed in the drug e-catalog. Drug procurement using an e-purchasing mechanism based on an e-catalog or if there are operational problems it can be done manually.

Based on the results of the study, it was found that drug services at Tjokrodipo Hospital Bandar Lampung City had referred to the list of drugs listed in Fornas and drug procurement at Tjokrodipo Hospital Bandar Lampung City had used the e-purchasing mechanism, there were complaints from BPJS participants regarding the procurement of drugs that did not exist for patients. BPJS so that patients are advised to look for drugs at other pharmacies and the lack of patient beds so that many patients pile up and queue to get an inpatient room.

Research conducted by Khariza (2015), on a descriptive study on factors that can influence the successful implementation of the National Health Insurance Program at the Menur Mental Hospital in Surabaya, it was found that the physical support facilities were not sufficient, this can be seen from the lack of physical support facilities in the inpatient room. Grades 1, 2, 3 are in the form of inadequate bed availability. Research conducted by Sidin et al (2015) on JKN Participant Satisfaction with Health Service Quality Using HCAHPS Indicators at the Inpatient Installation of the Stela Mari Hospital in Makassar in 2015 found inadequate facilities and infrastructure, absent patient guard chairs, old patient beds, fans that are no longer feasible, as well as other obstacles such as the comfort of patients who feel disturbed by noise from outside the treatment room so that patients cannot rest in peace. 
Based on the Regulation of the Minister of Health of the Republic of Indonesia No. 71 of 2013 concerning health services at BPJS states that Medical Devices are instruments, apparatus, machines, and/or implants that do not contain drugs that are used to prevent, diagnose, cure and alleviate disease, treat sick people and restore health to humans and/or form structure and improve body function. According to Gulo (2015) in his research states that the availability of health service facilities or facilities in carrying out health checks is a very important thing in order to achieve diagnosis enforcement, giving appropriate actions as well as supporters, companions and providers of results from the service system provided to the community.

\section{Process}

The health service process at Tjokrodipo Hospital Bandar Lampung City includes service flow, credentials, additional costs and BPJS claims. The flow of health services for the BPJS program at Tjokrodipo Hospital Bandar Lampung City starts from registration and queue numbers, file checks, examination of poly/medical services, there are two patient follow-ups, namely taking drugs at the pharmacy (pharmacy) and if you need special treatment, the patient will be treated further reference. But there is a specialization for emergency patients, Tjokrodipo Hospital Bandar Lampung City allows emergency patients to be immediately taken to the emergency room without going through a file check first.

Hospitals in the BPJS era are required to implement the clinical pathway service flow. Clinical pathway in a hospital is a process flow of patient service activities from incoming patients to patients returning home which is an integration of medical services, nursing services, pharmaceutical services and other health services. Clinical pathway is a pretreatment concept that is compiled based on standard procedures from each profession that refers to the service standards of their respective professions, adjusted to the strata of hospital service facilities (Rivany, 2011).

Research conducted by Hidayati et al (2017), concerning the Concept of Quality of Health Services based on the Expectations of Participants in the National Health Insurance. In this study, patients expect a long waiting time to get services. This dimension concerns care service, for example, includes officers who receive patients according to procedures, waiting times for fast service, officers serving patients appropriately, and officers conducting examinations quickly and precisely.

Research conducted by Amna (2012) in general the level of service implementation promised by the hospital management to patients has been carried out by health workers, but because there are still officers who are not available during working hours for any reason, it is necessary to re-regulate. As for officers who are less able to answer patient questions with convincing answers, it is necessary to increase the ability of human resources by sending them to training, sending study assignments or so that the officer often reads books so as to increase their knowledge.

Based on the results of the study, it was found that Tjokrodipo Hospital Bandar Lampung City had implemented the clinical pathway service flow. In carrying out the health service process, Tjokrodipo Hospital, Bandar Lampung City, has carried out credentials for each of its health workers. This is supported by all health workers who become informants at Tjokrodipo Hospital Bandar Lampung City can show No.SIP (Practice Permit) for nurses and doctors and No.SIPA (Pharmacy Practice Permit) for pharmacists. 
Based on the Minister of Health Regulation No.755 of 2011 concerning the Implementation of Medical Committees in Hospitals, it is stated that the Hospital's medical committee has the authority to implement clinical governance so that the Hospital's medical staff can maintain professionalism through a credential mechanism. Tjokrodipo Hospital Bandar Lampung City through the medical committee and the field of medical service human resources has the authority to perform credentials for health workers who perform medical clinical actions. Health services in the BPJS era do not justify additional costs in the process of providing health services.

The results of this study indicate that all informants said there was no additional cost unless the patient wanted to take a treatment class. This is in line with the informants who stated that they would be charged additional fees if they wanted to upgrade to the treatment class, but the fees paid were only the difference between the cost of the room treatment, while the cost of drugs and doctor services remained the same. According to the Regulation of the Minister of Health of the Republic of Indonesia No. 71 of 2013 states that participants who want a higher class of care than their rights, can increase their rights by participating in additional health insurance, or paying for the difference between the costs guaranteed by BPJS Kesehatan and the costs due to treatment class improvement. The BPJS claim process at Tjokrodipo Hospital, Bandar Lampung City is good because medical health workers always complete the administration for the claim process so that BPJS verifiers rarely return claim files from the hospital.

\section{Output}

The implementation of the BPJS program at Tjokrodipo Hospital, Bandar Lampung City has been carried out well and is in the process of progressing. The people of Bandar Lampung and outside Bandar Lampung have also understood the actual BPJS service procedures so that people think that BPJS health services are not so complicated in obtaining health services. However, during the pandemic, patients feel that the free health services provided are not good, on average, patients complain of a lack of equipment such as uncomfortable beds and rooms because there are many patients, lack of explanation by nurses for the services provided, nurses are less friendly to patients and patients feel the services provided not fast enough and not handled immediately. This can be seen in some of the patient's comments in the suggestion box.

The results of research conducted by Muliana et al (2015) at the Makassar City Hospital showed that there was a significant relationship between the dimensions of Reability, Tangible, Empathy, Responsiveness and Amenity with BPJS patient satisfaction in the inpatient unit of Makassar City Hospital. The results of Irwandy's research (2016) which in Makassar City showed that the level of satisfaction of JKN patients with hospital services was in the good category, namely $87.7 \%$ where this figure was above the set target of $85 \%$. Dimensions of measurement reliability $91.6 \%$, assurance of certainty $88.5 \%$, physical condition $88.5 \%$, understanding $89 \%$ and responsibility $89.7 \%$, it shows the influence of the quality of health services on patient satisfaction

\section{DISCUSSION}

\section{Analysis 5 M (Man, Machine, Methode, Money, Material) \\ Man}

Based on the results of the study, it was found that the availability of health human resources at Tjokrodipo Hospital Bandar Lampung City was not sufficient and not in accordance with the standards of class $\mathrm{C}$ hospitals, especially dentists and pediatricians who only numbered 1 
person, and the lack of general practitioners and nurses in isolation rooms because some doctors the general public and nurses are in self-isolation. Based on the Regulation of the Minister of Health of the Republic of Indonesia No. 56 of 2014 concerning Classification and Licensing of Hospitals, it is stated that the number of general practitioners for standard $\mathrm{C}$ class hospitals is 9 people, dentists are 2 people and specialist doctors for basic medical services are 2 people and each - 1 specialist doctor each for supporting medical services.

According to Notoadmojo (2010), there are two aspects that are seen in human resources, namely quantity and quality. According to the Ministry of Health of the Republic of Indonesia (1997), in order to provide guidance to improve knowledge and skills, the director of the hospital is obliged to improve the education of medical record officers with the provisions, namely: medical at least 20 hours. Regarding health human resources at Tjokrodipo Hospital, Bandar Lampung City, there have actually been efforts to increase in terms of numbers but the problem is the distance factor, which is a little difficult to invite, especially specialist doctors to stay at Tjokrodipo Hospital, Bandar Lampung City and Tjokrodipo Hospital, Bandar Lampung City, have not dared to pay honorarium doctor with package system. In this case, it is expected that the hospital will add to the health human resources at Tjokrodipo Hospital, Bandar Lampung City.

\section{Machine}

Based on the results of the study, it was found that drug services at Tjokrodipo Hospital Bandar Lampung City had referred to the list of drugs listed in Fornas and drug procurement at Tjokrodipo Hospital Bandar Lampung City had used the e-purchasing mechanism. This is supported by the results of interviews with informants who said that the drug procurement system at Tjokrodipo Hospital Bandar Lampung City had used an e-purchasing mechanism using a catalog system.

The results of the interview with informants regarding the medical equipment are complete and are in accordance with the medical equipment for class $\mathrm{C}$ hospitals. The mechanism for the procurement of medical devices starts from the lowest needs and then finally will be delivered to the Director of the Hospital and the Director of the Hospital who has the authority to request medical devices to PT. Based on the Regulation of the Minister of Health of the Republic of Indonesia No. 71 of 2013 concerning health services at BPJS states that medical devices are instruments, apparatus, machines, and/or implants that do not contain drugs that are used to prevent, diagnose, cure and alleviate disease, treat sick people and restore health to humans and/or form structure and improve body function. According to Gulo (2015) in his research states that the availability of health service facilities or facilities in carrying out health checks is a very important thing in order to achieve diagnosis enforcement, giving appropriate actions as well as supporters, companions and providers of results from the service system provided to the community.

\section{Methode}

Based on the results of the study, it was found that Tjokrodipo Hospital, Bandar Lampung City, did not have a special internal policy regarding the BPJS program. This is supported by the results of interviews with informants who said that the policy regarding the implementation of the BPJS program at Tjokrodipo Hospital Bandar Lampung City was the same, namely accepting patients from Bandar Lampung and patients outside Bandar Lampung without any specialization between the two. Policies are regulations or rules that are used as guidelines in the effort to implement BPJS in Tjokrodipo Hospital, Bandar Lampung City. One of the policies regarding BPJS in hospitals is the INA-CBG's tariff. According to 
the Regulation of the Health Social Security Administering Body Number 1 of 2014 states that the INA-CBG's tariff is the amount of claim payment by BPJS Health to Advanced Health Facilities for service packages based on disease diagnosis groupings. SOP (Standard Operating Procedure) is a system designed to make our work easier, tidy and orderly. This system contains a sequence of processes doing work from start to finish (Ekotama, S, 2015).

\section{Money}

The health service process at Tjokrodipo Hospital Bandar Lampung City includes service flow, credentials, additional costs and BPJS claims. The flow of health services for the JKN program at Tjokrodipo Hospital Bandar Lampung City starts from registration and queue numbers, file checks, examination of poly/medical services, patient follow-up is twofold, namely taking drugs at the pharmacy (pharmacy) and if special treatment is needed, the patient will be treated. further reference. But there is a specialization for emergency patients, Tjokrodipo Hospital Bandar Lampung City allows emergency patients to be immediately taken to the emergency room without going through a file check first.

Based on the results of the study, it was found that Tjokrodipo Hospital Bandar Lampung City had implemented the clinical pathway service flow. In carrying out the health service process, Tjokrodipo Hospital, Bandar Lampung City, has carried out credentials for each of its health workers. This is supported by all health workers who become informants at Tjokrodipo Hospital Bandar Lampung City can show No.SIP (Practice Permit) for nurses and doctors and No.SIPA (Pharmacy Practice Permit) for pharmacists. Based on the Minister of Health Regulation No.755 of 2011 concerning the Implementation of Medical Committees in Hospitals, it is stated that the Hospital's medical committee has the authority to implement clinical governance so that the Hospital's medical staff can maintain professionalism through a credential mechanism. Tjokrodipo Hospital Bandar Lampung City through the medical committee and the field of medical service human resources has the authority to perform credentials for health workers who perform medical clinical actions.

Health services in the BPJS era do not justify additional costs in the process of providing health services. The results of this study indicate that additional costs are given to patients who want to upgrade to treatment class. This is in line with the informants who stated that they would be charged additional fees if they wanted to upgrade to the treatment class, but the fees paid were only the difference between the cost of the room treatment, while the cost of drugs and doctor services remained the same. According to the Regulation of the Minister of Health of the Republic of Indonesia No. 71 of 2013 states that participants who want a higher class of care than their rights, can increase their rights by participating in additional health insurance, or paying for the difference between the costs guaranteed by BPJS Kesehatan and the costs to be paid as a result. treatment class improvement.

\section{Material}

The implementation of the BPJS program at Tjokrodipo Hospital, Bandar Lampung City has not been fully implemented properly. The people of Bandar Lampung do not understand the actual BPJS service procedures, so that people think that BPJS health services are complicated in obtaining health services. In the process of implementing activities, humans use materials because they are also considered as management tools or means to achieve goals (Manulang, 2012). According to the Regulation of the Minister of Health of the Republic of Indonesia Number 82 of 2013 article 3, every hospital is obliged to organize SIMRS. SIMRS can use applications with open source code provided by the ministry of health or use applications made by hospitals. 


\section{CONCLUSIONS}

Includes 5 M (Man, Machine, Method, Money, Material) analysis, namely the number of dentists and child specialists at Tjokrodipo Hospital Bandar Lampung City only 1 person, the lack of general practitioners and nurses in isolation rooms due to some health workers being infected with Covid19 and undergoing treatment self isolation. Procurement of drugs at Tjokrodipo Hospital, Bandar Lampung City has used an e-purchasing mechanism using a catalog system, but there are some drugs that are not available for BPJS patients so that patients have to look for other pharmacies. The Director of the Hospital, but during the current epidemic, the need for patient beds is still lacking due to the accumulation of patients, the policy regarding the implementation of the BPJS program is the same, namely accepting patients from Bandar Lampung and patients outside Bandar Lampung without any specialization between the two, does not justify additional costs in the process of providing health services and The implementation of the BPJS program at Tjokrodipo Hospital, Bandar Lampung City has not been fully implemented properly because there are still people who do not understand the BPJS service procedures

\section{REFERENCES}

Abdul Aziz, 2012. Analisis Tingkat Kepuasan Pasien Terhadap Pelayanan Keperawatan Prima Di Rsup Dr. M. Djamil Padang Tahun 2012. Tesis Universitas Andalas.

Azwar, 2010. Reabilitas dan Validitas. Yogyakarta: Pustaka Belajar.

Damopolii, R. V. (2016). Implementasi Kebijakan Pemerintah Daerah dalam Pelayanan Kesehatan Masyarakat (Studi di Kecamatan Kotamobagu Selatan Kota Kotamobagu). Politico: Jurnal Ilmu Politik, 3(1), 1168. Depkes RI, 2010. Indikator Pelayanan Rumah Sakit. Jakarta: Depkes RI

Depkes RI, 2014. Jaminan Kesehatan Nasional. Jakarta: Depkes RI

Depkes RI, 2014. Rencana Strategi Departemen Kesehatan. Jakarta: Depkes RI

Ernawati CT, Azkha N. Studi implementasi BLUD di UPTD balai kesehatan indera masyarakat provinsi Sumatera Barat tahun 2016. Jurnal Kesehatan Masyarakat Andalas. 2018;12(2):13-22.

Gulo, M, 2015. Analisis Rujukan Puskesmas Botombawo Kabupaten Nias dalam Era Jaminan Kesehatan Nasional Tahun 2015. Medan : Tesis Universitas Sumatera Utara

Harfina, D., S. S. Purwaningsih, D, Vibriyanti, S. Seftiani, A. S. Rahadian, P. Prasetyoputra, I. Hidayati, L. Feneteruma, Y. M. Sitohang \& T. A. Hafsari. (2019). Pemanfatan Jaminan Kesehatan Nasional bagi Pekerja Sektor Informal di Indonesia. Pusat Penelitian Kependudukan - LIPI, Jakarta.

Hasibuan MPS. (2016). Managemen sumber daya manusia. Jakarta: Bumi Aksara.

Henny. (2018). Analisis Unsur Manajemen Dalam Pengolahan Rekam Medis Di Rumah Sakit Tni Au-Lanud Roesmin Nurjadin. Pekanbaru: Jurnal Kesmas.

Junadi P. (2011). Survey Kepuasan Pasien di Rumah Sakit. Jakarta: Seminar RSPAD Gatot Subroto 
Kamiroki, E., Rorong, A., \& Ruru, J. (2018). Kualitas Pelayanan Kesehatan Gratis Di Rumah Sakit Umum Kabupaten Nabire Papua. Jurnal Administrasi Publik, 4(58).

Kemenkes. (2013). Buku Pegangan Sosialisasi Jaminan Kesehatan Nasional. (JKN) dalam Sistim Jaminan Sosial Nasional, Jakarta: Kementrian Kesehatan RI

Kementrian Kesehatan RI. (2013). Buku Pegangan Sosialisasi Jaminan Kesehatan Nasional (JKN) dalam Sistem Jaminan Sosial Nasional. 2013, Jakarta: Kementrian Kesehatan Republik Indonesia

Khariza HA. (2015). Program jaminan kesehatan nasional: studi deskriptif tentang faktorfaktor yang dapat mempengaruhi keberhasilan implementasi program jaminan kesehatan nasional di Rumah Sakit jiwa Menur Surabaya. Jurnal Kebijakan dan Managemen Publik. 2015;3(1):230-341.

Khariza, H. A. (2015). Program Kesehatan Nasional : Studi Deskriptif tentang Faktor-Faktor yang dapat Mempengaruhi Keberhasilan Implementasi Program Jaminan Kesehatan Nasional di Rumah Sakit Jiwa Menur Surabaya Vol.3 No.1. Surabaya : Universitas Airlangga

Miles, Mathew B. Michael Huberman. (2005). Analisis Data Kualitatif. Alfabeth.

Muninjaya AAG. Managemen kesehatan. Edisi keII. Jakarta: EGC; 2004.

Peraturan Presiden No 82 Tahun 2018 tentang Jaminan Kesehatan.

Peraturan Presiden Nomor 64 Tahun 2020 tentang Perubahan Kedua Atas Peraturan

Peraturan Presiden Republik Indonesia No 75 tahun 2019 tentang Perubahan Atas

Peraturan Presiden. (2006). Peraturan Presiden Republik Indonesia Nomor 39 Tahun 2006 tentang Tata Cara Pengendalian dan Evaluasi Pelaksanaan Rencana Pembangunan. Jakarta

Peraturan Menteri Kesehatan. (2013). Peraturan Menteri Kesehatan No.71 Tahun 2013 tentang Pelayanan Kesehatan pada Jaminan Kesehatan Nasional, Jakarta : Peraturan Menteri Kesehatan

Permenkes. (2011). Peraturan Menteri Kesehatan No. 755 Tahun 2011 tentang Penyelenggaraan Komite Medik di Rumah Sakit. Jakarta : Kementrian Kesehatan Republik Indonesia

PP Menkes. (2014). Peraturan Menteri Kesehatan No. 56 Tahun 2014 tentang Klasifikasi dan Perizinan Rumah Sakit, Jakarta : Peraturan Menteri Kesehatan

PP Menkes. (2014). Peraturan Menteri Kesehatan No.27 Tahun 2014 tentang Petunjuk Teknis Sistem Indonesian Case Base Groups (INA- CBG's), Jakarta: Peraturan Menteri Kesehatan

PP Menkes. (2014). Peraturan Menteri Kesehatan No.28 Tahun 2014 tentang Pedoman Pelaksanaan Program Jaminan Kesehatan Nasional, Jakarta: Peraturan Menteri Kesehatan 
PP Menkes. (2014). Profil Kesehatan Indonesia, Jakarta: Kementrian Kesehatan Republik Indonesia

PPRI. (2013). Peraturan Presiden Republik Indonesia Nomor 12 Tahun 2013 tentang Jaminan Kesehatan Nasional. Jakarta

Presiden Nomor 82 Tahun 2018 tentang Jaminan Kesehatan.

Putra, W. M., (2014). Analisis Implementasi Kebijakan Jaminan Kesehatan Nasional di Rumah Sakit Umum Kota Tangerang Selatan. Jakarta

Rivany. (2009). Indonesia Diagnosis Related Groups, Kesmas, Jurnal Kesehatan Masyarakat Nasional, Vol. 4, No. 1

Saputra M, Marlinae L, Rahman F, Rosadi D. (2015). Program jaminan kesehatan nasional dari aspek sumber daya Manusia Pelaksanaan Pelayanan Kesehatan. Jurnal Kesehatan Masyarakat.

Saswati, R. (2015). Analisis Pelaksanaan Program Jaminan Kesehatan Nasional (JKN) di Puskesmas Sawit Seberang Kecamatan Sawit Seberang Kabupaten Langkat Tahun 2015. Medan: Tesis Universitas Sumatera Utara

Subarsono. (2009). Analisis Kebijakan Publik. Yogyakarta: Pustaka Pelajar Sugiyono, 2011. Metode Penelitian Administrasi. Bandung: Alfabeta

Sumantri. (2013). Metodologi Penelitian Kesehatan. Jakarta: Kencana

Terjemahan dari Analyzing Qualitative Data, Jakarta: UI Press Parsons W, 2005. Public Policy. Jakarta: Prenada Media

Undang-Undang Nomor 40 Tahun 2004 tentang Sistem Jaminan Sosial Nasional.

Undang-Undang Republik Indonesia No 24 tahun 2011 tentang Badan Penyelenggara Jaminan Sosial.

Undang-Undang Republik Indonesia No 40 tahun 2004 tentang Sistem Jaminan Sosial Nasional.

UU Kesehatan No. 36 Tahun 2009 tentang Kesehatan

UU Kesehtan No.44 Tahun 2009 tentang Rumah Sakit

Widya wati dkk. (2019). Analisis Kualitas Pelayanan Program Jaminan Kesehatan Nasional di Ruang Rawat Inap Rumah Sakit X Kabupaten Kerinci. http://jurnal.fk.unand.ac.id. Diakses pada tanggal 21 Januari 2021

Zahry dkk. (2020). Kepesertaan Program Bpjs Kesehatan Di Tengah Wabah Pandemic Covid19. Lex Journal: Kajian Hukum \& Keadilan 